\title{
Retraction: Physiology and Pharmacology of the Cardiovascular Adrenergic System
}

\section{OPEN ACCESS}

Approved by:

George E. Billman,

The Ohio State University, USA

*Correspondence:

Frontiers Physiology Editorial Office physiology.editorial.office@

frontiersin.org

Specialty section:

This article was submitted to

Clinical and Translational Physiology,

a section of the journal

Frontiers in Physiology

Received: 24 November 2015

Accepted: 24 November 2015

Published: 27 November 2015

Citation:

Frontiers in Physiology Editorial Office (2015) Retraction: Physiology and

Pharmacology of the Cardiovascular Adrenergic System.

Front. Physiol. 6:379.

doi: 10.3389/fphys.2015.00379

\section{Frontiers in Physiology Editorial Office *}

\section{A retraction of the Review Article}

Physiology and pharmacology of the cardiovascular adrenergic system by Lymperopoulos, A. (2013) Front. Physiol. 4:240. doi: 10.3389/fphys.2013.00240

The journal has retracted the 4 September 2013 article cited above. Based on information discovered after publication and reported to Frontiers in June 2015, the article was examined, revealing that the complaint was valid and that the article should be retracted, because of an unacceptable level of similarity to another review article by Triposkiadis et al. (2009) published in the Journal of the American College of Cardiology. The retraction of the article was approved by the Field Chief Editor of Frontiers in Physiology. The author does not agree to the retraction or to the notice.

\section{REFERENCES}

Triposkiadis, F., Karayannis, G., Giamouzis, G., Skoularigis, J., Louridas, G., and Butler, J. (2009). The sympathetic nervous system in heart failure physiology, pathophysiology, and clinical implications. J. Am. Coll. Cardiol. 54, 1747-1762. doi: 10.1016/j.jacc.2009.05.015

Copyright (c) 2015 Frontiers in Physiology Editorial Office. This is an open-access article distributed under the terms of the Creative Commons Attribution License (CC BY). The use, distribution or reproduction in other forums is permitted, provided the original author(s) or licensor are credited and that the original publication in this journal is cited, in accordance with accepted academic practice. No use, distribution or reproduction is permitted which does not comply with these terms. 